\title{
BEYAZ PEYNİR MİKROBİYOTASINDA KÜLTÜROMİK VE SHOTGUN METAGENOMIK TEKNOLOJİLERİN DEĞERLENDİRİLMESİ
}

\author{
Zeynep Görkem Cerit ${ }^{1,2}$, Mehmet Cengiz Baloğlu ${ }^{3}$, Remziye Yılmaz, ${ }^{1, *}$ \\ ${ }^{1}$ Hacettepe Üniversitesi, Gıda Mühendisliği Bölümü, Beytepe Kampüsü, 06800, Ankara \\ ${ }^{2}$ Kastamonu Üniversitesi Gıda Mühendisliği Bölümü, Kastamonu \\ ${ }^{3}$ Kastamonu Üniversitesi Genetik ve Biyomühendislik Bölümü, Kastamonu
}

Geliş / Received: 07.12.2020; Kabul / Accepted: 24.03.2021; Online bask1 / Published online: 08.04.2021

Cerit, Z.G., Baloğlu, M.C., Yılmaz, R. (2021). Beyaz peynir mikrobiyotasında kültüromik ve shotgun metagenomik teknolojilerin değerlendirilmesi. GID A (2021) 46(3) 566-582 doi: 10.15237/gida.GD20136

Cerit, Z.G., Baloğlu, M.C., Yılmaz, R. (2021). Evaluation of culturomic and shotgun metagenomic technologies in white cheese microbiota. GIDA (2021) 46(3) 566-582 doi: 10.15237/gida.GD20136

\section{ÖZ}

Omik teknolojiler; DNA, RNA, genler, proteinler ve metabolitlerin araştırılması için kullanılan araçlar ve metotlardan oluşan sistematik yöntemler bütünüdür. Son yıllarda mikroorganizmaların tanımlanmasında ve işlevlerinin belirlenmesinde genomik, transkriptomik, proteomik ve metabolomik alanlarda yapılan çalışmalar artş göstermektedir. Genomik ve transkritptomik çalışmalar kapsamında mikroorganizmaların genom dizilerinin belirlenmesinde ve gen ifade analizlerinde yeni nesil dizileme sistemleri ile biyoinformatik araçlar birlikte kullanılmaktadır. Bu çalışmada, beyaz peynirin taşıdı̆̆ toplam mikrobiyel yükün oluşturduğu beyaz peynir mikrobiyotasının belirlenmesinde, kültürden bağımsız bir yöntem olan shotgun metagenomik ile kültüre dayalı bir yöntem olan ve mikroorganizmaların tanımlanmasına olanak sağlayan kültüromik metotları üzerinde durulmuştur. Çalışma ile yakın gelecekte beyaz peynir gibi geleneksel gida ürünlerinin yeni teknikler değerlendirilerek araşturllması gerekliliğinin önemi vurgulanmıştır. Kültüromik, metagenomik gibi yenilikçi teknikler, geleneksel gida ürünlerinin mikrobiyota tanımlanması üzerinde daha az belirsizlik ile çalısılmasına olanak sağlayabilmektedir.

Anahtar kelimeler: beyaz peynir, mikrobiyota, omik teknolojiler, metagenomik, kültüromik.

\section{EVALUATION OF CULTUROMICS AND SHOTGUN METAGENOMIC TECHNOLOGIES IN WHITE CHEESE MICROBIOTA}

\begin{abstract}
Omics technologies are a set of systematic methods consisting of tools and applications used to investigate genes, DNA, RNA, proteins and metabolites. In recent years, genomics, transcriptomics, proteomics and metabolomics have been mainly utilized in the identification and determination of microorganisms. Within the scope of genomic and transcriptomics studies, next generation sequencing systems and bioinformatics tools are used together to determine the genome sequences of microorganisms and gene expression analysis, respectively. In this study, shotgun metagenomics, the culture-independent method, and culture-dependent culturomics approach that allows identification of microorganisms are emphasized for the detection of white cheese microbiota. The study has been emphasized the importance of researching traditional food products such as white
\end{abstract}

* Yazışmalardan sorumlu yazar / Corresponding author

$\triangle$ : remziye06@gmail.com

Zeynep Görkem Cerit; ORCID no: 0000-0003-3955-9584

Mehmet Cengiz Baloğlu; ORCID no: 0000-0003-2976-7224

Remziye Yılmaz; ORCID no: 0000-0003-2041-1205 
cheese by evaluating new techniques in the future. Innovative techniques such as culturomics and metagenomics can enable the study of traditional food products to be studied with less uncertainty on the microbiota identification.

Keywords: white cheese, microbiota, omic technologies, metagenomics, culturomics.

\section{GİRIŞ}

Beyaz peynir mikrobiyotas1, peynir üretim sürecinde önemli bir rol oynar ve peynirin kendine özgü tat ve koku gibi organoleptik özelliklerinin oluşmasında etkilidir (Jonnala vd., 2018). Endüstride beyaz peynir üretimi için kullanılan laktik asit bakterilerinden oluşan starter kültür karışımları, sütte asitlik geliştirmenin yanında beyaz peynirin tat ve koku bileşiklerini oluşturmada görev alırlar. Endüstriyel beyaz peynir üretiminde çiğ süte uygulanan 1 ssl işlem ile çiğ sütte bulunan mikroorganizmaların tamamının yok edilmediği bildirilmiştir (Kable vd., 2016). Bunun yanında beyaz peynir üretim işletmelerinde peynirin temas ettiği ekipmandan peynire çeşitli mikroorganizmalar geçebilmektedir. Bu sebeple peynir mikrobiyotasına starter kültürün yanında peynire işlenen sütün mikrobiyotası ve işletme ekipmanının taşıdığı mikrobiyel yükün de etkisi olabileceği bildirilmiştir (Stellato vd., 2015). Starter kültür olmayan ve çiğ süt ve/veya çevresel kaynaklardan mikrobiyotaya katılan laktik asit bakterilerinin de beyaz peynirin organoleptik özellikleri ve besinsel içeriğininin gelişimine katkı sağlayabileceği bildirilmiştir (Wolfe vd., 2014).

Mikroorganizmaların tanımlanmasında kullanılan klasik kültürel yöntemlerin yanı sıra son yillarda omik teknolojilerde yaşanan gelişmeler mikrobiyota çalışmalarının daha doğru ve kesin bir şekilde yapılabilmesine olanak sağlamıştır (Jonnala vd., 2018; Escobar- Zepeda vd., 2018). Metagenomik, çevresel bir örnekte bulunan tüm genomların doğrudan izole edilerek genetik analizinin gerçekleştirilmesi olarak tanımlanabilir (Escobar-Zepeda, 2015; Chiu vd., 2019). Genetik materyalin dizilenmesiyle gerçekleştirilen metagenomik analizlerde yeni nesil sekanslama yöntemleri kullanılmaktadır. Kültüromik ise seçici besiyerlerinde farklı ortam şartlarında geliştirilen ve saf kültür olarak elde edilen izolatların Matriks Destekli Lazer Desorpsiyon İyonizasyon- Uçuş Zamanı Kütle Spektrometrisi (MALDI-TOF MS) ile tanımlanmasına olanak sağlayan bir yaklaşımdır (Garcia vd., 2016).
Bu çalışmanın amacı, bütünleşik omik yaklaşımı ile beyaz peynir üretim sürecine ilişkin süt, peynir ve çevre mikrobiyotasının dinamikleri hakkında laktik asit bakterileri açısından kapsamlı genel bir bakış sağlamaktır. Ayrıca bir mikrobiyota çalışmasında kültüre dayalı ve kültürden bağımsız iki yöntemin karşılaştırılmasının önemi üzerinde durulacaktır.

\section{Beyaz Peynir}

Peynir, sütün enzimler ya da organik asitler kullanılarak pıhtılaştırılması, oluşan pihtının baskılanarak peynir altı suyunun ayrilmasiyla oluşan, farklı yağ oranlarında ve farklı sertliklerde olabilen, çeşidine göre değişen renk, tat ve koku özelliklerine sahip bir süt ürünüdür. Dünyada 1000 'in üzerinde, Türkiye'de ise 50'ye yakın peynir çeşidinin olduğu bildirilmiştir (Togay vd., 2020). TEPGE Süt ve Süt Ürünleri Durum Tahmin Raporu ve Ulusal Süt Konseyi Süt Raporuna göre ülkemizde en çok tüketilen ve pazar payı en yüksek olan peynir çeşidi beyaz peynirdir (Anonymous, 2017; Anonymous, 2018). TÜİK Süt ve Süt Ürünleri Üretim İstatistikleri 2020 Mart ay1 raporuna göre Türkiye'de inek sütünden üretilen peynir miktarı bir önceki y1lın bahsedilen ayına kıyasla \%12,2 artış göstererek 63300 ton, manda, koyun ve keçi sütlerinden üretilen diğer peynirlerin üretimi ise $\% 14,8$ azalarak 2700 ton olmuştur (TÜİK, 2020). Türk Gıda Kodeksi Peynir Tebliği (Tebliğ No: 2015/6) uyarınca beyaz peynir "Hammaddenin peynir mayası kullanılarak pıhtılaştırılması ile elde edilen telemenin tekniğine uygun olarak işlenmesiyle üretilen, üretim aşamalarındaki farklılıklara göre taze veya olgunlaştırılmış olarak tanımlanabilen, çeşidine özgü karakteristik özellikler gösteren salamuralı peynir" olarak tanımlanmaktadır. Çizelge 1'de Türk Gıda Kodeksi Mikrobiyolojik Kriterler Tebliği (Tebliğ No: 2009/68) uyarınca beyaz peynirin uyması gereken mikrobiyolojik kriterlere yer verilmiştir. 
Çizelge 1. Beyaz peynirin mikrobiyolojik kriterleri

\begin{tabular}{llcccr} 
Gida & Mikroorganizmalar & \multicolumn{2}{c}{ Numune alma plan1 } & \multicolumn{2}{c}{ Limitler $\left(^{*}\right)$} \\
Peynir (eritme peynir & Enterobacteriaceae & $\mathrm{n}$ & $\mathrm{N}$ & $\mathrm{m}$ & $\mathrm{M}$ \\
hariç diğer tüm & S. aureus $\left(^{* *}\right)$ & 5 & 2 & $10^{3}$ & $10^{4}$ \\
peynirler) & Salmonella spp. & 5 & 2 & $10^{2}$ & $10^{3}$ \\
& L. monogytogenes & 5 & 0 & $0 / 25 \mathrm{~g}-\mathrm{mL}$ \\
& E. coli O157:H7 & 5 & 0 & $0 / 25 \mathrm{~g}-\mathrm{mL}$ \\
& 5 & 0 & $0 / 25 \mathrm{~g}-\mathrm{mL}$
\end{tabular}

$\left(^{*}\right)$ : Aksi belirtilmedikçe limit kob/g-mL olarak değerlendirilir.

$\left({ }^{*}\right)$ : Koagülaz pozitif stafilokoklar. n: Analize alınacak numune sayısını

c: "M" değeri taşıyabilecek en fazla numune sayısını

$\mathrm{m}:(\mathrm{n}-\mathrm{c})$ sayıdaki numunede bulunabilecek en fazla değeri

M: "c" sayıldaki numunede bulunabilecek en fazla değeri ifade etmektedir.

\section{Endüstriyel Beyaz Peynir Üretimi}

Beyaz peynirin kalitesi peynire işlenen sütün kimyasal kompozisyonuyla yakından ilişkilidir. Bu sebeple süt kimyasal ve mikrobiyolojik açıdan iyi kalitede olmalıdır. Buna göre işletmeye gelen süt; antibiyotik, deterjan ve kimyasal kalıntı içermemeli, mastitisli olmamalı, kolostrum içermemeli, laktasyonun ilk ve son safhalarında elde edilmemelidir. Kimyasal bileșimi normal olmayan, özellikle mastitisli hayvanlardan elde edilen sütlerin serum proteini içeriği yüksek, kazein içeriği ise düşüktür. Düşük kazein içeriğine sahip sütten üretilen peynirin randımanı düşmekte ve peynirde yumuşama problemi oluşmaktadır. Mikrobiyel açıdan peynire işlenen süt, koliform, Clostridium ve Bacillus cinsi bakterileri içermemelidir (Hayaloğlu vd., 2002).

Şekil 1'de endüstriyel beyaz peynir üretimi akış şeması verilmiştir. Endüstriyel beyaz peynir üretiminde ilk olarak işletmeye gelen çiğ süt kalite kontrolünden geçtikten sonra çiğ süt tanklarına alınır. Süt, üretime alınmadan önce ilk olarak basit filtreler ile gözle görülen kirliliklerden, daha sonra merkezkaç kuvveti ile çalışan seperatörlerle gözle görünmeyen yabanc1 maddelerden ayrıştırilır. Temizlenen sütün protein ve yă oranı ayarlanarak sütün standardizasyonu yapıllr. Daha sonra süt yüksek basınç altında $60-65^{\circ} \mathrm{C}$ sicaklıkta çok ince filtrelerden geçirilerek homojenizasyonu sağlanır. Homojenizasyon ile sütün içerdiği yağ globüllerinin çapı eşitlenir. Ön işlemlerin ardından süt $72-75^{\circ} \mathrm{C}$ 'de 15 saniye 1 sıl issleme maruz bırakılır ve hızlı bir şekilde $28-30^{\circ} \mathrm{C}^{\prime}$ ye soğutulur. Sütün bu sıcaklı̆ga soğutulmasının sebebi beyaz peynir starter kültürlerinin mezofilik özellikte laktik asit bakterilerinden oluşması ve bu sicaklıklarda optimum gelişmesidir. Starter eklendikten sonra süte $\mathrm{CaCl}_{2}$ eklenir. Bunun sebebi pastörizasyonda yüksek sıcaklığın etkisiyle ayrılan $\mathrm{Ca}^{+2}$ 'nin yapıya tekrar kazandırılmasıdır. Starter kültürün etkisiyle $\mathrm{pH}$ 5.5'e geldiğinde süte rennet enzimi (peynir mayası) ilave edilir. $\mathrm{Bu} \mathrm{pH}$ pıhtılaşmayı sağlayan rennet enziminin optimum aktivite gösterdiği pH'tır. Kazeinin dört alt biriminden biri olan kappa kazeinin sütün pihtılaşmasında önemli bir yeri vardir. Rennet enzimi kappa kazeinin 105. amino asidi fenilalanin ve 106. amino asidi metiyonin arasındaki bağı kırar (Şekil 2). Kırılan zincirde hidrofobik olan kısım para kappa-kazein (para kappa-casein) yapidan ayrilır ve pihtiyı oluşturur. Hidrofilik kısım olan glikomakropeptit (GMP) ise serum kısımda çözünerek yapıdan ayrilır. Pıhtı oluştuktan sonra $1 \mathrm{~cm}^{3}$ lük küpler halinde kırilıp baskilanarak fazla suyunu birakması sağlanır. Pıhtı baskılanırken cendere bezine sarılır ve üzerine ağıllık uygulanır. Cendere bezi beyaz peynirin bir yüzeyinde olan pütürlü şeklin oluşmasını sağlar. Pıhtının fazla suyunun alınmasıyla oluşan teleme $7 \mathrm{~cm}^{3}$ lük küpler halinde kesilir ve 24 saat salamurada (12-14 g/100 g $\mathrm{NaCl}$ ) bekletilir (Hayaloğlu vd., 2002). Salamurada bekletildikten sonra beyaz peynir, tercihe bağlı olarak olgunlaştırılmadan tüketime sunulabilmektedir. Salamuranın ardından taze beyaz peynir ambalajlanarak yine salamura (6 $\mathrm{g} / 100 \mathrm{~g} \mathrm{NaCl}$ ) içinde satşa sunulur. Olgunlaşturlarak tüketime sunulan beyaz peynirin olgunlaşturlmas1 ise $4-8^{\circ} \mathrm{C}^{\prime} \mathrm{de} \quad 60-90$ gün yapılmaktadır (Topçu ve Saldamlı, 2006). 
Sütün temizlenmesi, standardizasyonu ve homojenizasyonu

$\downarrow$

Pastörizasyon ve uygun sıcaklığa soğutma

$\downarrow$

Starter kültür inokülasyonu

$\downarrow$

$\mathrm{CaCl}_{2}$ ilavesi

$\downarrow$

Sütün pıhtılaştırılması (Maya ilavesi)

$\downarrow$

Pıhtı kesimi ve baskılama

$\downarrow$

Telemenin baskılanması ve peynir kalıp kesimi

$\downarrow$

Salamurada bekletme $(12-14 \mathrm{~g} / 100 \mathrm{~g} \mathrm{NaCl})$

$\downarrow$

Ambalajlama

Şekil 1. Beyaz peynir üretimi.
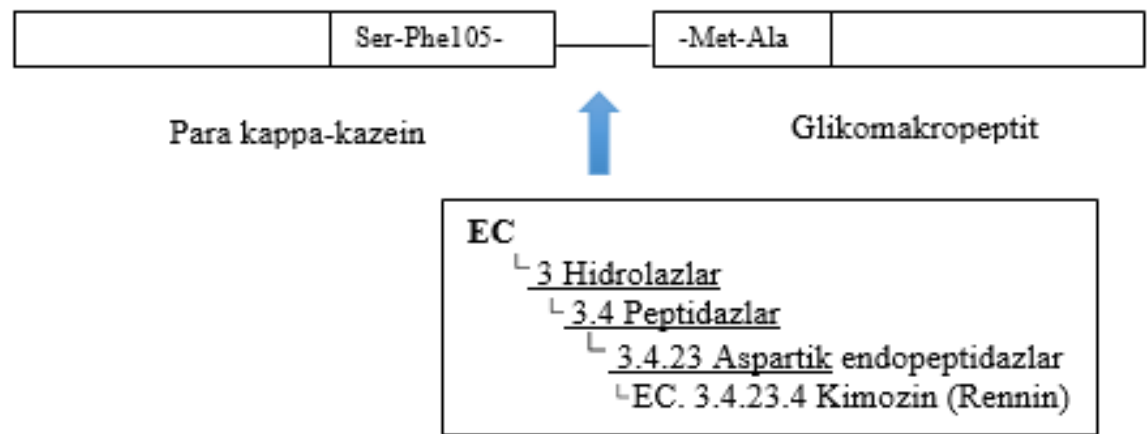

Şekil 2. Kazein zincirinin kırılması.

Beyaz Peynir Mikrobiyotas1

Mikrobiyota belirli ortamda bulunan mikrobiyel topluluğun tamamına verilen isimdir (Liu, 2016). Mikrobiyom tanımı, ilk kez Nobel ödüllü mikrobiyolog Joshua Lederberg tarafindan 2001 yılında yapılmıştur (Prescott, 2017). Buna göre, insan vücudunda bulunan kommensal, simbiyotik ve patojen mikroorganizmalardan oluşan ekosistemi ifade eden terim "mikrobiyom" olarak tanımlanmıştır. Daha sonra mikrobiyota ve 
mikrobiyom terimleri insan ve mikrobiyomu arasındaki etkileşimi açılamayı hedefleyen İnsan Mikrobiyom Projesi (HMP) tarafindan tekrar açıklanmıştır (Proctor vd., 2019). Günümüzde mikrobiyom, belirli bir ortamda bulunan bakteri, arkea, küf ve mayalardan oluşan mikrobiyel topluluğun oluşturduğu mikrobiyotanın toplam genomu olarak ifade edilmektedir (Knight vd., 2018).

Mikrobiyotanın bulunduğu konakçı ortamı insan, hayvan ya da bitki olabileceği gibi çevresel bir örnek de olabilir (Liu, 2016). Bu açiklamadan hareketle, bir peynir çeşidinin taşıdığ1 mikroorganizma topluluğu "peynir mikrobiyotası" olarak tanımlanabilir. Peynir mikrobiyotası, çok büyük oranda, kullanılan starter kültüre göre şekillenmektedir (Ercolini, 2004). Süt mikrobiyotası, peynir yapımında tüm süreçte önemli bir rol oynar ve peynire özgü lezzet ve doku gelişimine katkıda bulunur (Tilocca vd., 2019).

Starter kültürler ürüne istenilen tat, koku, aroma ve yap1 gibi özellikleri kazandırmak amacı ile kullanılan ve bilinen özelliklere sahip karışı mikroorganizma kültürleridir. Bunun yanında, peynir üretiminde işletmeye gelen çiğ sütün taşıdığ mikroorganizmalar da peynir mikrobiyotası ile ilişkilidir. Çünkü çiğ sütte bulunan mikroorganizmaların tamam1 pastörizasyon işlemi ile yok edilememektedir (Kable vd., 2016). Bu faktörlerin yanında peynir üretim işletmesinde peynirin temas ettiği ekipmandan peynire çeşitli mikroorganizmalar geçebilmektedir. $\mathrm{Bu}$ yüzden beyaz peynir mikrobiyotasını sadece eklenen starter kültür değil aynı zamanda çiğ süt mikrobiyotası ve işletme ekipmanlarının taşıdığı mikroorganizmalar gibi faktörler de etkilemektedir (Stellato vd., 2015).

Peynir mikrobiyotası, başlatıcı birincil mikroflora ve ikincil mikroflora olarak ikiye ayrilır (Tunail, 2009). Birincil mikroflora olan laktik asit bakterileri laktik asit fermantasyonuyla sütün asitliğini arttırırken olgunlaşma sürecinde de sahip oldukları enzimler sayesinde peynirin görünüss, tat, koku, tekstür gibi karakteristik özelliklerinin oluşumunu sağlarlar. İkincil mikroorganizmalar ise olgunlaşma sürecinde çeşitli organik asitlerin oluşumuna önemli katk1 sağlarlar. İkincil mikroflora peynir yüzeyinde ve/veya içinde gelişebilen başlatıcı kültür dışı laktik asit bakterileri, maya ve küflerden oluşabilmektedir. Günümüzde endüstriyel olarak üretilen beyaz peynirler genellikle taze peynir olarak olgunlaştrilmadan tüketime sunulmaktadır. $\mathrm{Bu}$ sebeple beyaz peynirin ikincil mikrofloras1 bulunmamaktadır (Tunail, 2009). Beyaz peynirin mikrobiyotasının oluşumunda ise starter kültür olarak kullanılan mikroorganizmaların yanında çevresel mikrobiyotanın, starter kültür olmayan mikroorganizmaların da etkisinin olabileceği bildirilmiştir (Jonnala vd., 2018). Literatür incelendiğinde, beyaz peynirde baskın tür olarak Lactococcus lactis ve Streptococcus thermophilus'un bulunduğu görülmektedir. Bu mikroorganizmalar özellikle peynirin olgunlaşmasının ilk aşamalarında daha belirgindir. Beyaz peynirde önemli tür olarak bildirilen diğer mikroorganizmalar Enterococcus faecalis ve E. faecium'dur. Lactobacillus fermentum, L. brevis, L. casei, L. plantarum, Leuconostoc mesenteroides subsp dextranicum ve Leu. lactis türleri de beyaz peynirde ağırlıklı olarak bulunan bakterilerdir. Ülkemizde beyaz peynir starter kültürü ile ilgili yapilan çalışmalar incelendiğinde özellikle Lc. lactis subsp. cremoris ve Lc. lactis subsp. lactisin, bunlarin yanında L. delbrueckii subsp. bulgaricus, St. thermophilus, $L$. helveticus ve $L$. plantarum bakterilerinin beyaz peynir starter kültürü olarak kullanılabileceği bildirilmiştir (Çizelge 2).

\section{Laktik Asit Bakterileri}

Laktik asit bakterileri, gıda endüstrisinde birçok fermente gıda ürününün üretiminde kullanılan önemli bakterilerdir. Laktik asit bakterileri, filogenetik olarak Lactobacillales takımına ait, 6 aile, 30'dan fazla cins ve 300 'den fazla türü barındıran bir bakteri grubudur (Endo vd., 2019). Lactococcus, Lacobacillus, Enterococcus, Streptococcus, Leuconostoc ve Pediococcus cinsleri başlica laktik asit bakterileridir. Lactococcus, Streptococcus, Lactobacillus ve Enterococcus cinsi laktik asit bakterilerinin taksonomik sınıflandırması Çizelge 3 'te verilmiştir (KEGG, 2020). Zheng vd. (2020) tarafindan yapılan bir çalışmada, laktik asit bakterilerinden Lactobacillaceae ve Leuconostocaceae ailelerinin 
sınıflandırılması tüm genom dizileme teknikleriyle yeniden değerlendirilmiştir. Çalışmanın çıtısı olarak Lactobacillus cinsinin 25 cinse ayrilmas1 önerilmiştir. Bunlar daha önceden de var olan fakat çalışmada tanımı tekrar yapılan Lactobacillus ve Paralactobacillus cinsleri ile 23 yeni cins; Levilactobacillus, Lentilactobacillus, Limosilactobacillus, Ligilactobacillus, Furfurilactobacillus, Amylolactobacillus, Secundilactobacillus, Holzapfelia,
Loigolactobacilus, Dellaglioa, Bombilactobacillus, Companilactobacillus, Lapidilactobacillus, Pancilactobacillus, Agrilactobacillus, Lacticaseibacillus, Latilactobacillus, Lactiplantibacillus, Fructilactobacillus, Acetilactobacillus, Apilactobacillus, Liquorilactobacillus ve Schleiferilactobacillus olmuştur. Tanımlanan bu yeni cinslerin temsil ettiği eski Lactobacillus cinsi bakterilerin sadece cins isimleri değişmiş olup tür ve suş isimleri aynı kalmıştır.

Çizelge 2. Beyaz peynir starter kültürü olarak kullanılabileceği bildirilen mikroorganizmalar (Cerit, 2020)

Starter kültür

Lc. lactis subsp. lactis

Lc. lactis subsp. cremoris

Lc. lactis subsp. lactis

Lc. lactis subsp. cremoris

L. helveticus

Lc. lactis subsp. lactis

Lc. lactis subsp. cremoris

Lc. lactis subsp. lactis

Lc. lactis subsp. cremoris

Lc. lactis subsp. lactis

Lc. lactis subsp. cremoris

Mezofilik kültür+ E. faecium EF031 (ek kültür)

Mezofilik kültür+ E. faecium M74 (ek kültür)

Lc. lactis

E. faecium

L. plantarum

Lc. lactis subsp. lactis/ cremoris

L. delbrueckii subsp. bulgaricus

St. thermophilus

Lc. lactis subsp. lactis

Lc. lactis subsp. cremoris

Yarrowia lipolytica

Debaryomyces hansenii

Lc. lactis subsp. lactis

Lc. lactis subsp. cremoris

St. salivarius subsp. thermophilus

Lc. lactis subsp. lactis

Lc. lactis subsp. cremoris

St. thermophilus

Laktik asit bakterileri Gram pozitif, Sporplactobacillus inulinus dişında spor oluşturmayan, anaerobik, aerobik ya da fakültatif aerobik olan, kok ya da çubuk şekilli, karbonhidrat metabolizmasının ana fermantasyon ürünlerinden biri olan laktik asiti üreten oldukça değerli mikroorganizmalardır (Tunail, 2009). Bu
Kaynak

Uysal, 1996

Gürsoy vd., 2001

Dağdemir, 2001

Hayaloğlu vd., 2002

Tunail, 2009

Bulat, 2011

Ertürkmen vd., 2015

Chr. Hansen, 2014

Kesenkaş, 2015

Danisco, 2019

Natural Food Culture, 2019

bakteriler aynı zamanda, asidi tolere edebilen, katalaz ve oksidaz negatif olan, nitratı redükte edemeyen mikroorganizmalardır. Laktik asit bakterileri düşük guanin ve sitozin $(G+C)$ oranına (\%35-53) sahiptirler ve genom büyüklükleri genel olarak 1.8-3.4 Mbp arasında değişmektedir (Yllmaz vd., 2015). 
Çizelge 3. Lactococcus, Streptococcus, Lactobacillus ve Enterococcus cinsi laktik asit bakterilerinin taksonomik siniflandirmasi

$\begin{array}{lllll} & \text { Lactococcus } & \text { Streptococcus } & \text { Lactobacillus } & \text { Enterococcus } \\ \text { Alem } & \text { Bacteria } & \text { Bacteria } & \text { Bacteria } & \text { Bacteria } \\ \text { Şube } & \text { Firmicutes } & \text { Firmicutes } & \text { Firmicutes } & \text { Firmicutes } \\ \text { Sinıf } & \text { Bacilli } & \text { Bacilli } & \text { Bacilli } & \text { Bacilli } \\ \text { Takım } & \text { Lactobacillales } & \text { Lactobacillales } & \text { Lactobacillales } & \text { Lactobacillales } \\ \text { Aile } & \text { Streptococcaceae } & \text { Streptococcaceae } & \text { Lactobacillaceae } & \text { Enterococcaceae } \\ \text { Cins } & \text { Lactococcus } & \text { Streptococcus } & \text { Lactobacillus } & \text { Enterococcus }\end{array}$

Laktik asit bakterileri gelişmek için karbonhidtratlar, amino asitler, vitamin, mineral ve bazen de yağ asitleri ve peptitler gibi zengin besinlere ihtiyaç duymaktadırlar. Bundan dolayı da besin içeriği yüksek olan ortamlarda bulunurlar. Bunlara, gastrointestinal sistem; mide ve bağırsak, vajinal yollar, ağız boşluğu, bitki yüzeyleri, silaj ve süt ve süt ürünleri gibi çok çeşitli ortamlar örnek olarak verilebilmektedir (Endo vd., 2019). Laktik asit bakterileri bulundukları ortamın içeriğindeki hegzoslan fermente ederek lastik asit oluştururlar ve fermantasyon sonucu ürettikleri son ürüne göre iki gruba ayrilırlar. Hegzoslardan sadece laktik asit (\%90-100) oluşturanlar homofermantatif laktik asit bakterileri, laktik asidin (\%50) yanısıra etanol, asetat ve $\mathrm{CO}_{2}$ oluşturanlar ise heterofermantatif laktik asit bakterileridir.

Laktik asit fermatasyonu sonucu ortaya çıkan laktik asit, asetik asit, asetaldehit ve diasetil gibi aromatik bileşikler sayesinde yoğurt, peynir çeşitleri, kefir, ekşi krema, fermente çiğ sucuk, tarhana gibi kendine özgü tadı ve aroması olan ürünler elde edilmektedir. Bundan dolayı seçilen bazı laktik asit bakterisi suşlarından starter kültürler, aroma geliştirici kültürler ve probiyotik kültürler üretilmektedir. Starter kültür özelliği gösteren laktik asit bakterilerinin ürettiği laktik asit ile ortamın asitliği artar ve asidi tolere edemeyen mikroorganizmaların bu ortamda yaşaması güçleşir. Laktik asit bakterileri asidi tolere edebildikleri için bu ortamda rekabetçi konumdadır ve böylelikle patojen ve diğer mikroorganizmaların inhibe edilmesini sağlarlar.

Bunun yanında laktik asit bakterilerinin metabolitlerinden olan hidrojen peroksit, diasetil, bakteriyosin ve amonyak gibi maddeler diğer mikroorganizmalara karşı antimikrobiyal özellik göstermektedir. Böylece bir gida maddesinde laktik asit bakterilerinin varlığ ile istenmeyen mikroorganizmaların inhibe edilmesi sağlanabilmektedir. Laktik asit bakterileri gida endüstrisinde önemli bir yeri olan fermente gidaların üretilmesinde starter kültür olarak kullanılmalanı, asitlik ve aroma geliştirici olmaları, antimikrobiyal aktiviteleri ve probiyotik olmaları gibi özelliklerinden dolayı gıda endüstrisinde çok önemli bir yer tutmaktadırlar.

\section{Laktik Asit Bakterilerini Tanımlama Yöntemleri}

Laktik asit bakterilerinin tanımlanması süt endüstrisi için büyük önem arz etmektedir. Laktik asit bakterilerinin tanımlanması ile süt ve süt ürünlerinin mikrobiyotası hakkında edinilen bilgiler starter kültür ve peynir üretim teknolojilerinin geliştirilmesinde kullanılarak süt endüstrisine ekonomik anlamda katk1 sağlayabilmektedir. Ayrıca süt ve ürünlerinin mikrobiyotasının belirlenmesi, süt ürünlerinin kalitatif ve duyusal özelliklerinin ve güvenilirliğinin kontrol edilmesi için oldukça önemlidir (Tilocca vd., 2019).

100 y1lı aşkin süredir mikrobiyolojide, mikroorganizmaların katı besiyeri kullanılarak izole edilmesi ve uygulanan bazı testlerle bu izolatların morfolojik, biyokimyasal ve fizyolojik özelliklerinin belirlenmesiyle tanımlanması 
esasına dayalı klasik kültürel yöntemler kullanılmaktadır. Mikroorganizmalar ile ilgili çalışmalar, 1676 yllında Leeuwenhoek'un ağız mikroorganizmalariyla ilgili raporundan günümüzde kullanilan moleküler yöntemler ile tanımlama çalışmalarına kadar uzun bir yol kat etmiştir. Mikroorganizmaların izolasyonuyla ilgili çalışmalar ilk olarak bilim insanlarının patates dilimleri ve jelatin gibi katı besi ortamlanında mikroorganizmaları kültüre etmeleriyle başlamıştır. İzolasyon yöntemlerinin bulunması mikroorganizmaların "Görünmeyen organizmalar" olarak adlandırdığı dönemlerde mikroorganizmalanın keşfi, mikroskop altında gözlemlenebilmesi ve onlann fizyolojilerinin anlaşılabilmesi adına ilk basamak olmuştur (Escobar- Zepeda vd., 2015).

1970'lerin sonunda ribozomal RNA (rRNA) genlerinin moleküler markırlar olarak kullanılabileceği görüşünün ortaya atılması ve bunula birlikte Sanger sekanslamanın ortaya çıkış1 mikroorganizmaların tanımlanmasında bir devrim yaratmıştır (Escobar- Zepeda vd., 2015). Ardindan Polimeraz zincir reaksiyonu, rRNA genlerinin klonlanması ve dizilenmesi, Denature edici Gradient Jel Elektroforezi (DGGE) gibi moleküler yöntemler mikroorganizmaların tanımlanmasında kullanılmaya başlanmıştır (Ercolini, 2013; Yllmaz vd., 2015). Metagenomik analizlerin ortaya çıkması, mikroorganizmaların tanımlanmasında önemli bir adım olmuştur. Saf kültürlerin izolasyonuna dayalı tanımlama tekniklerinin aksine metagenomik analizler kültüre edilemeyen mikroorganizmaların da tanımlanabilmesine olanak sağlamaktadır (Zhang vd., 2019).

\section{Laktik Asit Bakterilerinin Klasik Kültürel Yöntemlerle Tanımlanması}

Klasik kültürel yöntemlerle tanımlamada ilk aşama mikroorganizmaların saf kültür halinde izole edilmeleridir. Bunun için uygun seçici besiyerlerinden yararlanılmaktadır. Laktik asit bakterilerinin geliştirilmesi ve izolasyonunda MRS Agar ve MRS Broth, M17 Agar ve M17 Broth, Kanamycin Esculin Azide Agar gibi yüksek besleyici özelliğe sahip seçici besiyerleri kullanılmaktadır. Laktik asit bakterilerinin tanımlanmasında ilk olarak seçici besiyerinden uygun makroskopik morfolojiye sahip koloniler seçilerek saf kültür olarak elde edilir. Ardından izolatların mikroskobik morfolojileri incelenerek kaydedilir. Sonrasinda izolatların Gram reaksiyonu ve katalaz aktiviteleri belirlenmektedir. Sporsuz çubuk veya kok şeklinde, Gram pozitif ve Katalaz negatif özellik gösteren izolatlar laktik asit bakterileri olarak belirlenmektedir. Klasik kültürel yöntemlerde bakterilerin cins düzeyinde tanımlanması amaciyla bir takım biyokimyasal ve fizyolojik testler uygulanmaktadır. Bunlara; farklı sıcaklık ve $\mathrm{pH}$ değerleri ile farklı tuz konsantrasyonlarında gelişme, glukozdan gaz oluşturma, karbonhidrat fermentasyon testleri, antibiyotik duyarllığı, arjininden amonyak üretimi, indol, Voges-Proskauer, jelatin hidrolizi ve üreaz testleri, sukrozdan dekstran oluşturma gibi testler örnek gösterilebilir.

Kültüromik yaklaşımı ile Laktik Asit Bakterilerinin İzolasyonu ve Tanımlanması

Kültüromik, seçici besiyerlerinde farklı ortam şartlarında geliştirilen ve saf kültür olarak elde edilen izolatların Matriks Destekli Lazer Desorpsiyon İyonizasyon- Uçuş Zamanı Kütle Spektrometrisi (MALDI-TOF MS, Matrix Assisted Laser Desorption Ionization Time of Flight Mass Spectrometry) ile tanımlanmasina olanak sağlayan bir yaklaşımdır (Garcia vd., 2016; Nacef vd., 2017). Şekil 3'te kültüromik yaklaşımı özetlenmiştir. MALDI-TOF MS, mikroorganizmaların proteinlerinin iyonize edilerek bir elektrik alandan geçirilmesi ile protein profillerinin çıkarılması esasına dayanır (Santos vd., 2016). MALDI-TOF MS'te tanimlamanin ilk basamağ1 saf kültür olarak elde edilen izolatın hedef plaka üzerinde matriks solüsyonu ile muamele edilip kristalleştirilmesidir (Harnpicharnchai vd., 2020). Matriks solüsyonu ile kaplanan ve kuruması beklenen örnek sonrasinda hedef plaka ile cihaza yüklenir. Cihaz içi vakumu sağlandıktan sonra hedef plaka lazer ışınına maruz bırakılır. Kristalize halde bulunan proteinler lazer ışınının etkisiyle iyonlaşır ve protonlanmış iyonlar elde edilir. İyon bulutu bir elektrik alanda hızlandırılarak uçuş tüpünden geçirilir. İyonların uçuş tüpünde geçirdikleri süre (Time of Flight, TOF) uçuş süresi analizatörleri ile 
hesaplanır. Bu süre iyonların kütlesiyle ilisskilidir. İyonların uçuş tüpünde aldıkları yol tamamlandığında, her bir izolat için kütle spektrumları elde edilir. $\mathrm{Bu}$ spektrumlar veri tabanında bulunan veriler ile karşılaştırllır ve mikroorganizmaların tanımlanması gerçekleştirilir (Lagier vd., 2018).

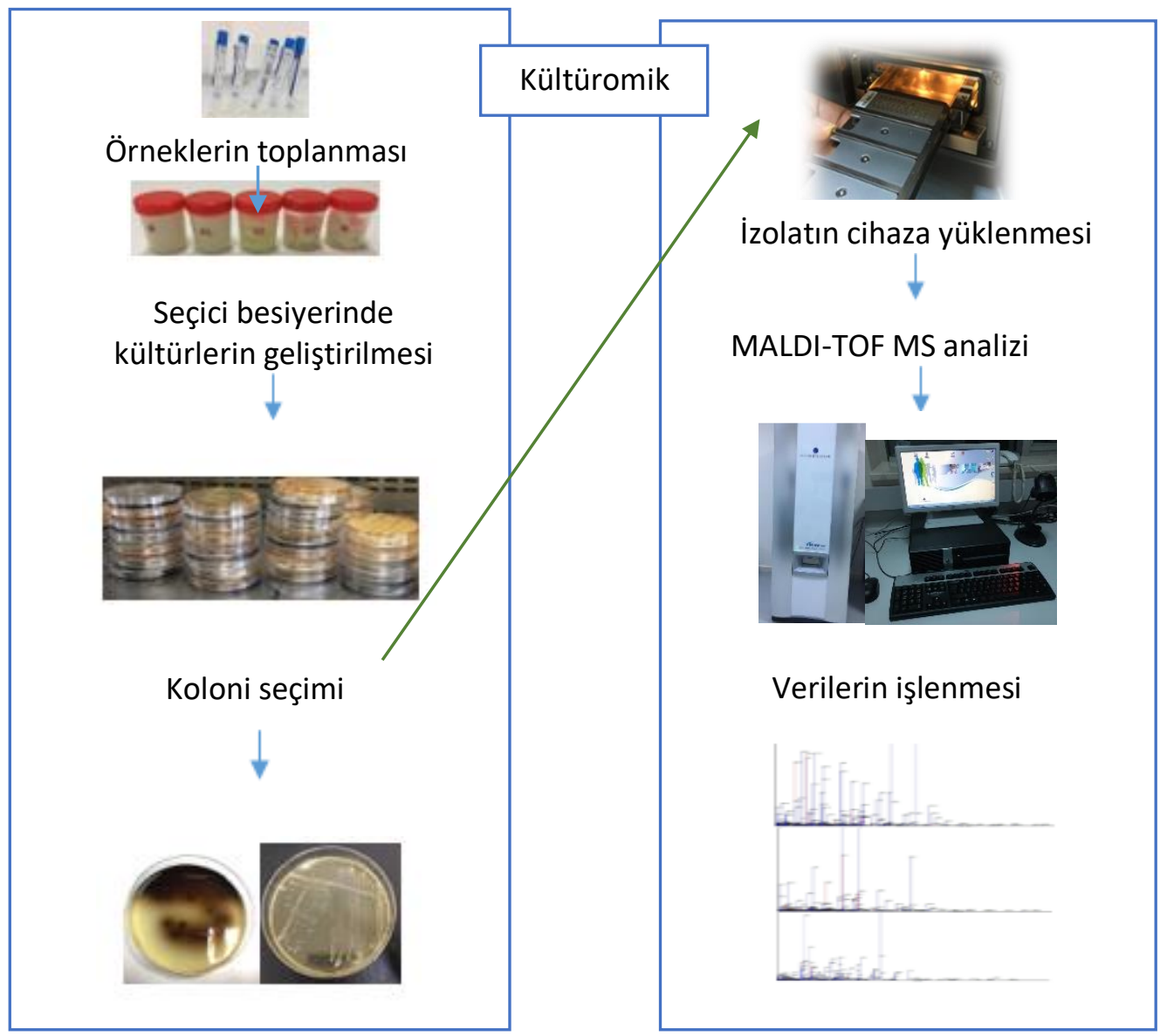

Şekil 3. Kültüromik yaklaşımının şematik gösterimi (Orijinal resimler kullanılmıştrr).

Kültüromik yaklaşımının, mikrobiyel toplulukta az yoğunlukta bulunan mikroorganizmaların da tanımlanması, hizlı ve ekonomik olması, yalnızca canlı mikroorganizmaların tanımlanmasına olanak sağlaması ve tanımlanan kültürlerin ileri çalıșmalar için saklanmasına izin vermesi gibi avantajları vardır. Ancak kültüromik yöntemi ile sadece kültüre edilebilen mikroorganizmaların tanımlanması mümkün olmaktadır (Nacef vd., 2017).

\section{Metagenomik Analizler}

Mikrobiyel topluluk bir ortamda aynı anda birlikte var olan organizmalar grubudur.
Mikroorganizmaların fizyolojilerini anlamak için kullanılan yöntemlerin, Robert Koch'un katı halde besin ögelerini mikroorganizmaların sayısını belirlemek ve onlar1 mikroskop altunda görüntülemek için kullanmasıyla başladığı ifade edilebilir. Ancak, Petri kabında gelişen ve mikroskopta görüntülenen mikroorganizma sayıs1 arasındaki büyük fark, mikroorganizmaları kültüre etme yöntemlerinin yetersiz kaldığını göstermiştir (Handelsman, 2004; Sielaff vd., 2019). Dökme Plak Yönteminde Büyük Farklılık (Great Plate Count Anomaly) olarak isimlendirilen bu yetersizlik, var olan mikroorganizmalanın yaklașık olarak yalnizca \%1'nin in vitro olarak 
belirlenebildiğini göstermiştir (Escobar-Zepeda vd., 2015; Serra vd., 2019). Elde edilen bu veriyle beraber belli bir ortamda bulunan mikroorganizmaların belirlenmesi ve tanımlama çalışmalarının yapılabilmesi için yeni yöntemlerin gerekliliği ortaya çıkmışır (Şekil 4).

Metagenomik, çevresel bir örnekte bulunan tüm genomların doğrudan izole edilerek genetik analizinin yapilması olarak tanımlanabilir (Chiu vd., 2019). Genetik materyalin dizilenmesiyle gerçekleştirilen metagenomik analizler yeni nesil dizileme yöntemleriyle gerçekleştirilir. Yeni nesil dizileme sistemleriyle bitki, bakteri, maya, küf, virüs gibi mikroorganizmaların genomlarının ultra hızlı olarak, yüksek doğrulukla dizilenmesi mümkündür. Günümüzde kullanılan yeni nesil dizileme sistemleri, Illumina Genome Analyzer, Applied BioSystem SOLID, Complete
Genomics, Helios, Pacific Biosciences ve IonTorrent'tir (Jongman vd., 2020; Nair ve Bhat, 2020).

Metagenomik analizler amplikon dizileme ve shotgun olarak ikiye ayrilmaktadır. Amplikon dizilemede, örnekten tüm mikroorganizmaların toplam DNA ekstraksiyonu yapıldıktan sonra taksonomik bilgi veren belirli gen bölgeleri hedeflenir. Bunlara, nesiller boyu korunmuş ve taksonomik bilgi veren $16 S r R N A, 18 S r R N A$ ve ITS genleri örnek verilebilir (Parente vd., 2020). $\mathrm{Bu}$ hedeflenen genler spesifik primerler yardımıyla PCR ile amplifiye edilirler. Amplifiye edilen gen bölgeleri dizilenir ve biyoinformatik araçlarla bu diziler anlamlı verilere dönüştürülerek mikroorganizmalar tanımlanmış olur (Ranjan, 2016; Breitwieser vd., 2019; Serra vd., 2019).

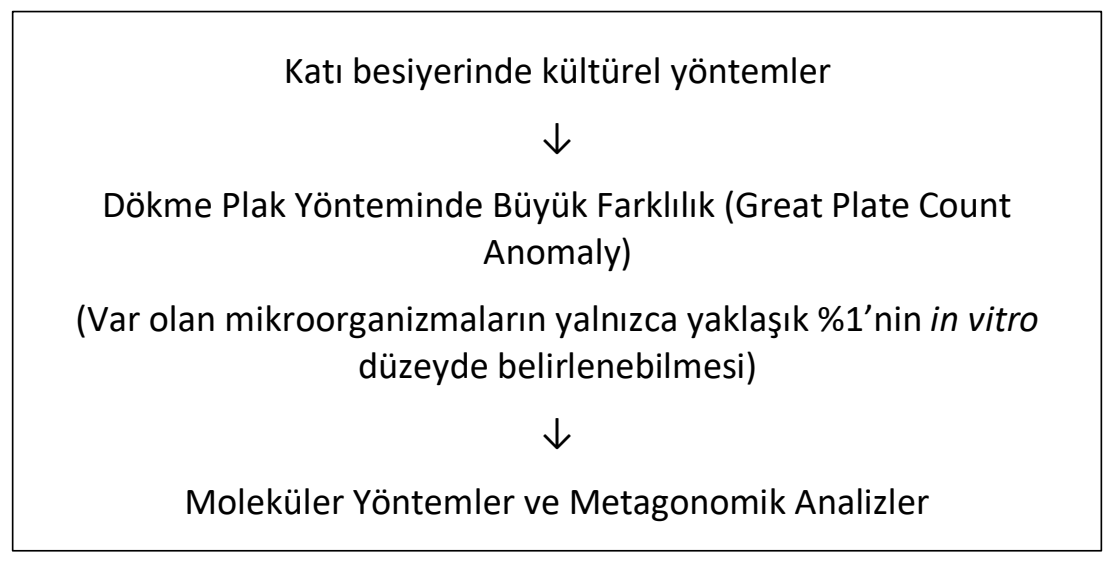

Şekil 4. Metagenomik analizlerin ortaya çıkışı

Shotgun dizileme ise; örnekte bulunan tüm genomun rastgele parçalarının dizilendiği sistemdir. Shotgun dizileme ve amplikon dizilemenin en önemli farkı tüm genom shotgun dizileme ile mikroorganizmaların tür düzeyinde tanımlanmasında amplikon dizilemeyle tanımlamaya kıyasla daha güvenilir sonuçlar elde edilmesidir (Ranjan, 2016; Thoendel vd., 2019). Tüm genom shotgun dizileme ve amplikon dizilemede farklı veri tabanları kullanımaktadır ve shotgun dizilemede daha büyük ham veri elde edilmektedir (Deurenberg vd., 2017; EscobarZepeda vd., 2018; Jagadeesan vd., 2019).
Tüm genom shotgun dizileme daha ayrintil incelenecek olursa, ilk aşama yine ortamda bulunan mikroorganizmalarnn genetik materyalinin doğrudan ekstrakte edilmesidir. $\mathrm{Bu}$ elde edilen genetik materyal o ortamda bulunan tüm mikroorganizmalarin genomunu kapsamaktadır (Zhou vd., 2019). Toplam genom olarak doğrudan izole edilen DNA'lar dizileme için çok uzundur. Bu yüzden öncelikle DNA'ların küçük fragmentlere (200-600 bp) mekanik ya da enzimatik yollarla ayrılması gerekir. Küçük parçalara ayrılan DNA fragmentlerinin iki ucuna adaptörler eklenir. Bu adaptörler kütüphanenin oluşturulması sırasında DNA fragmentlerinin bir 
yüzeye bağlanması için gereklidir. Daha sonra bu DNA fragmentleri $95^{\circ} \mathrm{C}^{\prime}$ ye isitilarak denatüre edilir ve tek zincirli hale getirilir. Tek zincirli hale getirilen DNA fragmentlerinin bir yüzeye tutunması sağlanır. Bu yüzey kullanılan yeni nesil sekanslama tekniğine göre değişim göstermektedir (Kader vd. 2016, Jagadeesan vd., 2019). Illumina sistemde bu amaç için oligonükleotitlerle kaplanmış bir akış hücresi kullanılırken, Ion Torentte boncuklar (bead) kullanılır. Yüzeye tutunan DNA parçaları kütüphaneleri oluşturur. Devamında bu kütüphanelerden kümeler oluşturulur. Bu amaçla ortama eklenmiş olan nükleotitler, polimeraz enzimi, primerler ve buffer ile DNA'lann eşlenmesi gerçekleşir. Çift zincirli hale gelen DNA'lar tekrar denatüre edilir ve orijinal zincir uzaklaştırilır. Sonra kalan zincirler tekrar eşlenirler bu döngü defalarca tekrarlanır ve bu şekilde kümeler oluşturulmuş olur. Dizileme aşamasına geçildiğinde DNA'ların eşlenmesinde floresanla modifiye edilmiş nükleotitler kullanılır (Ranjan, 2016; Zhang vd., 2019). Böylece her bir nükleotitin eklenmesinde 1şık kaynağı ile birlikte hangi nükleotitin eklendiği görüntülenir ve böylece sırayla eklenen nükleotitler dizilenmiş olur. Dizileme işleminden sonra elde edilen verilerin dizi analizi biyoinformatik araçlar yardımıyla gerçekleştirilir. $\mathrm{Bu}$ analizlerle hedeflenen ortamda hangi mikroorganizmalar1 olduğu ve bunların ne oranda bulunduğu tespit edilebilir (Jagadeesan vd., 2019; Weiss vd., 2019).

Gıdalar bakteri, maya, küf gibi organizmaları birlikte bulundurur ve bu mikroorganizmalar birbirleriyle etkileşimde bulunarak gidaların fermantasyonundan sorumludur veya bozulmasina sebep olur. Son yirmi yilda geliştirilen kültürden bağımsız metotlar ile gıda üretimi, depolaması ve dağıtımı süreçleri fermantasyon ve bozulma dinamikleri incelenmiştir (Cocolin ve Ercolini 2015; Serra vd., 2019). Gıdalarda gerçekleştirilen bu çalışmaların; g1da patojenlerinin tayini, gidalarda bozulmalara yol açan mikroorganizmaların tayini, fermantasyon süresince mikroorganizma değişiminin izlenmesi, potansiyel starter ya da yararlı mikroorganizmalann belirlenmesi gibi çıtıları olmaktadır.
Ülkemizde beyaz peynirin mikrobiyel kompozisyonunun belirlenmesine yönelik yapılan çalışmalar incelendiğinde genellikle klasik kültürel yöntemler ve biyokimyasal testlerin kullanıldığ1, bunun yanında son zamanlarda 16S rRNA dizileme yönteminin öne çıtı̆̆ 1 görülmektedir (Hayaloğlu vd., 2002; Ertürkmen vd., 2015; Arslan, 2017).

Arslan (2017) yaptığı çalışmada, Erzurum başta olmak üzere Türkiye'nin çeşitli bölgelerinden topladığ 1 beyaz peynirlerden laktik asit bakterilerinin izolasyonunu ve $A P I, 16 S r R N A$ gen analizi ve rep-PCR yöntemleri ile identifikasyonunu gerçekleştirmiştir. Buna göre Lactobacillus kefiri, L. brevis, L. casei, L. paracasei, Pediococcus lolii, Prolinoborus fasciculus, Staphylococcus haemolyticus, Lysnibacillus sinduriensis, P. parvulus, $L$. paraplantarum, Staphylococcus bominis, L. buchneri, L. plantarum, Enterococcus faecium, Micrococcus yunnanensis, Microbacterium paraoxydans ve Rotbia dentocariosa türlerine ait 42 adet izolat tanımlanmıştır.

Dec vd. (2016) tarafindan kümes hayvanlarından izole edilen Lactobacillus cinsine ait bakterilerin tanımlanması amacıyla yapılan çalışmada 16SARDRA ve MALDI-TOF yöntemleri kullanılmıs ve sonuçta; $L$. salivarius, $L$. jobnsonii ve $L$. ingluviei türleri baskın mikroorganizmalar olarak kaydedilmiştir. Ayrıca MALDI-TOF MS'in diğer yöntemlere kıyasla çok daha hızlı bir yöntem olduğu bildirilmiştir.

Literatür incelendiğinde, çeşitli fermante gida ürünlerinin mikrobiyotasının belirlenmesi ve fermantasyon sürecinde rolü olan mikroorganizmaların aydınlatılabilmesi amaciyla yüksek çıktılı yeni nesil dizileme yönemleriyle çalışmalar yapıldığı görülmektedir. $\mathrm{Bu}$ gida ürünleri; kefir (Nalbantoğlu vd., 2014; Garofalo vd., 2015; Walsh vd., 2016; Verce vd., 2020), pirinç şarabı (Bora vd., 2016), tahıl sirkesi (Wu vd., 2017), üzüm ve şarap (Sternes vd., 2017; Wei vd., 2018; Cerutti vd., 2019), kakao taneleri (Agyirifo, 2019; Serra vd., 2019), kahve (Pothakos vd., 2020), çiğ süt (Kable vd., 2016; Doyle vd., 2017), sucuk (Ferrocino vd., 2018) ve peynirdir (Wolfe vd., 2014; Dalmasso vd, 2016; Dugat- 
Bony vd., 2016; Guidone vd., 2016; EscobarZepeda vd., 2016; Domingos-Lopes vd., 2017; Duru vd., 2018; Savaşan ve Beyaz, 2019).

Wolfe vd. (2014) yaptığ1 çalışmada eskitilmiş peynirin kabuk kısmının mikrobiyel çeşitliliğinin belirlenebilmesi, mikroorganizmaların metabolizmalarının ve fonksiyonlarının araşurrlabilmesi ve bu peynirin kabuk kısmını oluşuran mikroorganizmalara ait bir model oluşturulabilmesi amacıyla, Avrupa'dan Amerika'ya 10 farklı ülkede starter kültür kullanılarak üretilen ve olgunlaştırılan 137 adet eskitilmiş peynirin kabuk kısmında PCR bazlı amplikon dizileme yapılmıştır. Bakteri komuniteleri için $16 S r R N A$ ve küf komuniteleri için ITS bölgeleri dizilenmiştir. Çalışmanın sonucunda tüm örneklerde $\% 1$ 'den fazla bulunan ve bu oranla baskın mikroorganizma olan 14 adet bakteri ve 10 adet küf cinsi tespit edilmiştir. Tespit edilen cins sayısinın sinırlı olmasinın, bu mikroorganizmaların starter kültür kaynaklı olmasından ötürü olduğu bildirilmiştir. Ancak bunun yanında bakterilerin \%60'inın küflerin ise $\% 25$ lik kısmının starter kültür olmayan mikroorganizmalar olduğu tespit edilmiştir. Starter kültür kaynaklı olmayan bu mikroorganizmaların çevresel kaynaklardan gelmiş olabileceği bildirilmiştir. Çevresel kaynaklardan gelen bu mikroorganizmaların peynirlerin yap1, tat, koku gibi özelliklerinin oluşmasında katkısının olabileceği bildirilmiştir.

Guidone vd. (2016) tarafindan yapılan çalışmada, farklı asidifikasyon yöntemleri ile üretilen yüksek nemli Mozzarella peynirlerinden alınan örneklerin mikrobiyel kompozisyonu yüksek çıtılı yöntemlerle incelenmiştir. Örneklerden yapılan DNA ekstraksiyon işleminin ardından $165 r \mathrm{RN} A$ genlerinin V1-V3 bölgeleri amplifiye edilmiş ve pirosekanslama yöntemi ile dizilenmiştir. Kalite kontrol ve filtreleme işlemleri QIIME 1.8.0 yazılımı ile gerçekleştirilmiştir. Çalışmanın sonuçlarına göre, starter kültür kullanılan peynirlerde Streptococcus thermophilus baskın tür olarak gözlenmiştir. Bunun yanında diğer laktik asit bakterileri ve \%0,01-1 oranında bozulmaya sebep olan mikroorganizmalar gözlenmiştir. Sitrik asit kullanılan 5 örnek ve etiket bilgisi olmayan 5 örnekte ise laktik asit bakterileri, psikotrofik mikroorganizmalar ve Enterobacteriaceae ailesine ait mikroorganizmalardan oluşan yüksek mikrobiyel çeşitlilik gözlenmiştir. Sonuç olarak sitrik asit kullanılan ve etiket bilgisi içermeyen peynirlerin mikrobiyel çeşitliliğinin daha fazla olduğu bulunmuştur. $\mathrm{Bu}$ yöntemle starter kültürlerle üretilen Mozzarella peynirlerinin diğer yöntemlerle üretilen peynirlerden mikrobiyel açıdan farklılığı kanıtlanmış ve peynir endüstrisinde yapılan hilelerin anlaşılabileceği belirtilmiştir.

Verce vd. (2020) tarafindan yapılan çalışmada, kefir mikrobiyotasının belirlenmesi amaciyla shotgun dizileme yapılmış ve yeni bir bakteri türü keşfedilmiştir. Bunun için fermantasyonun 2 farkl1 aşamasında hem kefir tanelerinden hem de kefirin sulu kısmından olmak üzere 4 örnek alınmıştır. Örneklerden DNA ekstraksiyonu yapılmış, shotgun dizileme Ion PGM cihazında gerçekleştirilmiş ve elde edilen diziler BLAST, Kraken ve Kaiju gibi biyoinformatik araçlar kullanılarak anlamlandırılmıştır. Çalışma sonunda kefirde Lactobacillus harbinensis, Lactobacillus bilgardii, Lactobacillus nagelii, Lactobacillus paracasei ve çeşitli Lactobacillus türleri bulunmuştur. Bunun yanında Bifidobacterium aquikefiri ile Saccharomyces cerevisiae ve Dekekera bruxellensis mayalar1 da tespit edilmiştir. Ayrıca çalışmada Shothun metagenomik dizileme ile Oenococcus oeni ve Oenococcus kitaharae türleri ile ilişkili yeni bir Oenococcus türü tespit edildiği ve bu türün Candidatus Oenococcus aquikefiri olarak isimlendirildiği raporlanmıştır.

\section{SONUÇ}

Son yillarda mikroorganizmaların tanımlanmasında klasik kültürel yöntemlerin yanı sıra genetik materyale dayalı moleküler tekniklerin kullanımı oldukça yaygınlaşmıştır. Kültüre dayalı moleküler yöntemlerin yanında kültürden bağımsız metagenomik teknolojisi çevresel örneğin taşıdığ mikrobiyel yükün toplam genomunun dizilenmesine olanak sağlaması ile mikroorganizmaların tanımlanmasina ve mikrobiyota çalışmalarına yeni bir bakış açısı getirmiştir. Bu nedenle, endüstriyel olarak üretilen beyaz peynir mikrobiyotasının belirlenmesinde 
MALDI-TOF MS temelli kültüromik yaklaşımı ve shotgun dizileme temelli metagenomik teknolojilerin birlikte kullanılması önemli görülmektedir. Bunun yanında beyaz peynir işletmesinde üretim süresince peynire doğrudan ve/veya dolaylı yoldan temas eden ekipman mikrobiyotasının belirlenmesi ve bunun beyaz peynir mikrobiyotasına katkısının aydınlatılması endüstriyel açıdan önem arz etmektedir. Ayrıca, amac1 geleneksel gida ürünlerinin mikrobiyal çeşitliliğini keşfetmek ve bu çeşitliliğin insan sağlığ1 açısından önemini ortaya koyacak ileri çalışmalar için yenilikçi yöntemlerin değerlendirilmesi gereklidir.

\section{TEŞEKKÜR}

$\mathrm{Bu}$ çalş̧ma TAGEM ve MAYSA GIDA tarafindan TAGEM/18/AR-GE/31 nolu sayll proje ile maddi olarak desteklenmiştir. Desteklerinden doyalı TAGEM Kurumuna ve MAYSA GIDA'ya teşekkür ederiz.

\section{ÇIKAR ÇATIŞMASI BEYANI}

Yazarların, başka kişiler ve/veya kurumlar ile çıar çatışması bulunmamaktadır.

\section{YAZAR KATKILARI}

Bu çalışmada tüm yazarların katkısı eşittir.

\section{KAYNAKLAR}

Agyirifo, D.S., Wamalwa, M., Otwe, E.P., Galyuon, I., Runo, S., Takrama, J., Ngeranwa, J. (2019). Metagenomics analysis of cocoa bean fermentation microbiome identifying species diversity and putative functional capabilities, Heliyon 5(7): e02170, doi: 10.1016/j.heliyon.2019.e02170.

Anonymous (2009). Türk Gıda Kodeksi. Mikrobiyolojik Kriterler Tebliğinde Değişiklik Yapılması Hakkında Tebliğ (2009/68). Tarım ve Köyişleri Bakanlığı. 8 Ocak 2010 tarih ve 27456 sayll Resmi Gazete, Ankara.

Anonymous (2015). Türk Gida Kodeksi. Peynir Tebliği (2015/6). Tarım ve Köyişleri Bakanlığı 8 Şubat 2015 tarih ve 29261 sayll Resmi Gazete, Ankara.

Anonymous (2020) Tarımsal Ekonomi ve Politika Geliştirme Enstitüsü Müdürlügü (TEPGE) 2017-
2018 Süt ve Süt Ürünleri Durum Tahmin Raporu. https://arastirma.tarimorman.gov.tr/tepge/Belg eler/PDF\%20Durum-

Tahmin\%20Raporlar\%C4\%B1/2017-

2018\%20Durum-

\%20Tahmin $\% 20$ Raporlar $\%$ C4\%B1/S\%C3\%BCt $\% 20$ Durum $\% 20$ Tahmin\%20Raporu\%2020172018-305.pdf (Erişim tarihi: 15 Mart 2020).

Anonymous (2020). Ulusal Süt Konseyi 2018 Süt Raporu. https://ulusalsutkonseyi.org.tr/wpcontent/uploads/Sut_Raporu_2018_Web_Kapa kli.pdf (Erişim tarihi: 15 Mart 2020).

Arslan, S. (2017). Türkiye'nin farklı yörelerinden toplanan beyaz peynir örneklerinden laktik asit bakterilerinin izolasyonu, identifikasyonu ve moleküler karakterizasyonu. Atatürk Üniversitesi Fen Bilimleri Enstitüsü Moleküler Biyoloji ve Genetik Anabilim Dalı Yüksek Lisans Tezi, Erzurum, Türkiye, $116 \mathrm{~s}$.

Bora, S.S., Keot, J., Das, S. Sarma, K., Barooah, M. (2016). Metagenomics analysis of microbial communities associated with a traditional rice wine starter culture (Xaj-pitha) of Assam, India. 3 Biotech, 6(2): 153, doi: 10.1007/s13205-016-04711.

Breitwieser, F. P., Lu, J., Salzberg, S. L. (2019). A review of methods and databases for metagenomic classification and assembly. Brief Bioinform, 20(4): 1125-1136, doi: 10.1093/bib/bbx120.

Cerit, Z.G. (2020). Beyaz peynir ve süt işleme tesisinden izole edilen mikrobiyotanın karakterizasyonu. Hacettepe Üniversitesi Fen Bilimleri Enstitüsü Gıda Mühendisliği Anabilim Dalı, Yüksek Lisans Tezi, Ankara, Türkiye 165 s.

Cerutti, F., Cravero, D., Costantini, A., Pulcini, L., Modesto, P., Acutis, P.L., Vaudano, E., Peletto, S. (2019). Impact of DNA purification method and primer selection on 16S rRNA gene metabarcoding on wine. OENO One, 53 (3). doi: 10.20870/oeno-one.2019.53.3.2368.

Cocolin, L., Ercolini, D. (2015). Zooming into food-associated microbial consortia: a 'cultural' evolution. Curr Opin Food Sci, 2: 43-50, doi: 10.1016/j.cofs.2015.01.003. 
Dalmasso, A., Río, M.D., Civera, T., Pattono, D., Cardazzo, B., Bottero, M.T. (2016). Characterization of microbiota in Plaisentif cheese by high-throughput sequencing. Lebensm Wiss Technol, 69: 490-496, doi: 10.1016/j.lwt.2016.02.004.

Dec, M., Puchalski, A., Urban-Chmiel, R., Wernicki, A. (2016). 16S-ARDRA and MALDITOF mass spectrometry as tools for identification of Lactobacillus bacteria isolated from poultry. BMC Microbiol, 16 (105), doi: 10.1186/s12866-016-0732-5

Deurenberg, R.H., Bathoorn, E., Chlebowicz, M.A., Couto, N., Ferdous, M., García-Cobos, S., Kooistra-Smid, A.M., Raangs, E.C., Rosema, S., Veloo, A.C., Zhou, K., Friedrich, A.W., Rossen, J.W. (2017). Application of next generation sequencing in clinical microbiology and infection prevention.J Biotechnol, 243: 16-24, doi: 10.1016/j.jbiotec.2016.12.022.

Domingos-Lopesa, M.F.P., Stanton, C., Ross, P.R., Dapkevicius, M.L.E., Silva, C.C.G. (2017). Genetic diversity, safety and technological characterization of lactic acid bacteria isolated from artisanal Pico cheese. Food Microbiol, 63:178190, doi: 10.1016/j.fm.2016.11.014.

Doyle, C.J., Gleeson, D.E., O'Toole, P.W., Cotter, P.D. (2017). Impacts of Seasonal Housing and Teat Preparation on Raw Milk Microbiota: a High-Throughput Sequencing Study. Appl Environ Microbiol, 83: 2, doi: 10.1128/AEM.0269416.

Dugat-Bony, E., Garnier, L., Denonfoux, J., Ferreira, S., Sarthou, A., Bonnarme, P., Irlinger, F. (2016). Highlighting the microbial diversity of 12 French cheese varieties. Int J Food Microbiol, 238: 265-273, doi: 10.1016/j.ijfoodmicro.2016.09.026.

Duru, I.C., Laine, P., Andreevskaya, M., Paulin, L., Kananen, S., Tynkkynen, S., Auvinen, P., Smolander, O.P. (2018). Metagenomic and metatranscriptomic analysis of the microbial community in Swiss-type Maasdam cheese during ripening. Int J Food Microbiol, 281: 10-22 doi: 10.1016/j.ijfoodmicro.2018.05.017.
Ercolini, D., Mauriello, G., Blaiotta, G., Moschetti, G., Coppola, S. (2004). PCR-DGGE Fingerprints Of Microbial Succession During A Manufacture Of Traditional Water Buffalo Mozzarella Cheese. J Appl Microbiol, 96(2): 263-70, doi: 10.1046/j.1365-2672.2003.02146.x.

Ercolini, D. (2013). High-Throughput Sequencing And Metagenomics: Moving Forward In The Culture-Independent Analysis Of Food Microbial Ecology. Appl. Environ. Microbiol., 79 3148-3155, doi: 10.1128/AEM.00256-13.

Ertürkmen, P., Öner, Z. (2015) "Beyaz Peynir Örneklerinden İzole Edilen Laktik Asit Bakterilerinin Başlatıcı (Starter) Kültür Özelliklerinin Biyokimyasal Yöntemlerle Belirlenmesi". Süleyman Demirel Üniversitesi Fen Bilimleri Enstitüsü Dergisi 19: 9-16, doi: 10.19113/sdufbed.25545.

Escobar-Zepeda, A., Vera-Ponce De León, A., Sanchez-Flores, A. (2015). The Road to Metagenomics: From Microbiology to DNA Sequencing Technologies and Bioinformatics. Front Genet, 6 (348), doi: 10.3389 / fgene.2015.00348.

Escobar-Zepeda, A., Sanchez-Flores, A., Barucha, M. Q. (2016). Metagenomic analysis of a Mexican ripened cheese reveals a unique complex microbiota. Food Microbiol, 57: 116-127, doi: 10.1016/j.fm.2016.02.004.

Escobar-Zepeda, A., Godoy-Lozano, E.E., Raggi, L. (2018). Analysis of sequencing strategies and tools for taxonomic annotation: Defining standards for progressive metagenomics. Sci Rep, 8, doi: 10.1038/s41598-018-30515-5.

Ferrocino, I., Bellio, A., Giordano, M., Macori, G., Romano, A., Rantsiou, K., Decastelli, L., Cocolin, L. (2018). Shotgun Metagenomics and Volatilome Profile of the Microbiota of Fermented Sausages. ApplEnviron Microbiol, 84(3): e02120-17. doi: 10.1128/AEM.02120-17.

Garofalo, C., Osimani, A., Milanović, V., Aquilanti, L., Filippis, F.D., Stellato, G., Mauro, S.D., Turchetti, B., Buzzini, P., Ercolini, D., Clementi, F. (2015). Bacteria and yeast microbiota in milk kefir grains from different Italian 
regions. Food Microbiol, 49: 123-133, doi: 10.1016/j.fm.2015.01.017.

Guidone A., Zotta, T., Matera, A., Ricciardi, A., Filippis, F.D., Ercolini, D., Parente,E. (2016). The microbiota of high-moisture mozzarella cheese produced with different acidification methods. Int J Food Microbiol, 216: 9-17, doi: 10.1016/j.ijfoodmicro.2015.09.002.

Handelsman, J. (2004). Metagenomics: Application of Genomics to Uncultured Microorganisms. Microbiol Mol Biol Rev, 68(4): 669685, doi: 10.1128/MMBR.68.4.669-685.2004.

Harnpicharnchai, P., Jaresitthikunchai, J., Seesang, M., Jindamorakot, S., Tanapongpipat, S., Ingsriswang, S. (2020). Characterization of Yeast and Bacterial Type Strains with Food and Agricultural Applications by MALDI-TOF Mass Spectrometry Biotypin. Hanguk Misaengmul Saengmyong Konghakhoe Chi, 48(2): 138-147. doi: 10.4014/mbl.1910.10008.

Hayaloğlu, A.A., Güven, M., P. F. Fox. (2002). Microbiological, Biochemical and Technological Properties Of Turkish White Cheese 'Beyaz Peynir’. Int Dairy J, 12(8): 635-648. doi: 10.4172/2572-4134.1000117.

Jagadeesan, B., Gerner-Smidt, P., Allard, M.W., Leuillet, S., Winkler, A., Xiao, Y., Chaffron, S., Vossen, J.V., Tang, S., Katase, M., McClure, P., Kimura, B., Chai, L.C., Chapman, J., Grant, K. (2019). The use of next generation sequencing for improving food safety: Translation into practice. Food microbiol, 79: 96-115, doi: 10.1016/j.fm.2018.11.005.

Jonnala, B.R.Y., McSweeney, P.L.H., Sheehan, J.J., Cotter, P.D. (2018). Sequencing of the Cheese Microbiome and Its Relevance to Industry. Front Microbiol, 23(9): 1020, doi: 10.3389/fmicb.2018.01020.

Jongman, M., Carmichael, P.C., Bill, M. (2020). Technological Advances in Phytopathogen Detection and Metagenome Profiling Techniques, Curr Microbiol, 77: 675-681, doi: 10.1007/s00284-020-01881-z.

Kable, M.E., Srisengfa, Y., Laird, M., Zaragoza, J.L., Mcleod, J., Heidenreich, J.M., Marco, M.L.
(2016). The Core and Seasonal Microbiota of Raw Bovine Milk in Tanker Trucks and the Impact of Transfer to a Milk Processing Facility. mBio, 7, doi: 10.1128/mBio.00836-16.

Kader, T., Goode, D. L., Wong, S. Q., Connaughton, J., Rowley, S. M., Devereux, L., Byrne, D., B. F., Stephen, Arnau, G. M., Tothill, R. W., Campbell I. G., Gorringe, K. L. (2016). Copy number analysis by low coverage whole genome sequencing using ultra low-input DNA from formalin-fixed paraffin embedded tumor tissue, Genome Med, 8(121), doi: 10.1186/s13073016-0375-z.

KEGG GENOME Database (2020). Organisms and ecosystems with genome sequence information. https://www.genome.jp/kegg/ genome.html (Erişim tarihi: 20 Şubat 2020).

Knight R., Vrbanac, A., Taylor, B. C., Aksenov, A., Callewaert, C., Debelius, J., Gonzalez, A., Kosciolek, T., McCall, L. I., McDonald, D., Melnik, A. V., Morton, J. T., Navas, J., Quinn, R.A., Sanders, J. G., Swafford, A. D., Thompson, L. R., Tripathi, Xu, Z. Z., Zaneveld, J. R., Zhu, Q., Caporaso J. G., Dorrestein, P. C. (2018). Best practices for analysing microbiomes, Nat Rev Microbiol, 16: 410-422, doi: 10.1038/s41579-0180029-9.

Lagier, J., Dubourg, G., Million, M., Cadoret, F., Bilen, M., Fenollar, F., Levasseur, A., Rolain, J.M., Fournier, P.E., Raoult, D. (2018). Culturing the human microbiota and culturomics. Nat Rev Microbiol, 16: 540-550, doi:. 10.1038/s41579-0180041-0.

Liu, X. (2016). Microbiome. Yale J Biol Med, 89(3): 275-276, doi: 10.3389/fmicb.2017.02224.

Nair, H.P., Bhat, S.G. (2020). Metagenomic data on bacterial diversity profiling of Arabian sea sediment by amplicon sequencing, Data Brief, 28, doi: 10.1016/j.dib.2019.104791.

Nacef, M., Chevalier, M., Chollet, S., Drider, D., Flahaut, C. (2017). MALDI-TOF mass spectrometry for the identification of lactic acid bacteria isolated from a French cheese: The Maroilles. Int J Food Microbiol, 247: 2-8, doi: 10.1016/j.ijfoodmicro.2016.07.005. 
Nalbantoğlu, U., Cakar, A., Dogan, H., Abaci, N., Ustek, D., Sayood, K., Can, H., (2014). Metagenomic analysis of the microbial community in kefir grains. Food Microbiol, 41: 4251, doi: 10.1016/j.fm.2014.01.014.

Parente, E., Ricciardi, A., Zotta, T. (2020). The microbiota of dairy milk: A review. Int Dairy J, 107: 104714, doi: 10.1016/j.idairyj.2020.104714.

Pothakos, V., Vuyst, L.D., Zhang, S.J., Bruyn, F.D., Verce, M., Torres, J., Callan, M., Moccand, C., Weckx, S. (2020). Temporal shotgun metagenomics of an Ecuadorian coffee fermentation process highlights the predominance of lactic acid bacteria. Curr Res Biotechnol, 2:1-15, doi: 10.1016/j.crbiot.2020.02.001.

Prescott, S.L. (2017). History of medicine: Origin of the term microbiome and why it matters. Hum Microb J, 4: 24-25, doi: 10.1016/j.humic.2017.05.004.

Ranjan, R., Rani, A., Metwally, A.A., McGee, H.S., Perkins, D.L. (2016). Analysis of the microbiome: Advantages of whole genome shotgun versus $16 \mathrm{~S}$ amplicon sequencing. Biochem Biophys Res Commun, 469(4): 967-977, doi: 10.1016/j.bbrc.2015.12.083.

Santos, I.C., Hildenbrandbc, Z.L., Schug, K.A. (2016). Applications of MALDI-TOF MS in environmental microbiology. Analyst, 141: 2827-2837, doi: 10.1039/C6AN00131A.

Savaşan, S., Beyaz, D. (2019). Erken Olgunlaşma Dönemindeki Geleneksel Peynir Mikrobiyomunun Metagenomik Analizi. Vet Mikrobiyol, 30(1): 27-35, doi: 10.35864/EVMD.586548.

Serra, J.L., Moura, F.G., Pereira, G.V., Soccol, C.R., Rogez, H.L., Darnet, S. (2019). Determination of the microbial community in Amazonian cocoa bean fermentation by Illuminabased metagenomic sequencing. Lebensm Wiss Technol, 106: 229-239, doi: 10.1016/J.LWT.2019.02.038.

Sielaff, A.C., Urbaniak, C., Mohan, G.B., Stepanov, V.G., Tran, Q.H., Wood, J.M., Minich, J.J., McDonald, D., Mayer, T., Knight, R.,
Karouia, F., Fox, G.E., Venkateswaran, K. (2019). Characterization of the total and viable bacterial and fungal communities associated with the International Space Station surfaces. Microbiome, 7 , doi: 10.1186/s40168-019-0666-x.

Stellato, G., Filippis, F.D., Storia, A.L., Ercolini, D. (2015). Coexistence of Lactic Acid Bacteria and Potential Spoilage Microbiota in a Dairy Processing Environment. Appl Environ Microbiol, 81(22): 7893-7904, doi: 10.1128/AEM.02294-15.

Sternes, P.R., Lee, D., Kutyna, D.R., Borneman, A.R. (2017). A combined meta-barcoding and shotgun metagenomic analysis of spontaneous wine fermentation. GigaScience, 6: 1-10, doi: 10.1093/gigascience/gix040.

Tilocca, B., Costanzo, N., Morittu, V.M., Spina, A.A., Soggiu, A., Britti, D., Roncada, P., Piras, C. (2019). Milk microbiota: Characterization methods and role in cheese production. $J$ proteomics, 210: $103534, \quad$ doi: 10.1016/j.jprot.2019.103534.

Togay, S.O., Capece, A., Siesto, G., Aksu, H., Altunatmaz, S.S., Aksu, F., Romano, P., Yuceer, Y.K. (2020). Molecular characterization of yeasts isolated from traditional Turkish cheeses. Food Sci. Technol, doi: 10.1590/ fst.24319.

Topçu, A., Saldamli, I. (2006). Proteolytical, Chemical, Textural and Sensorial Changes During the Ripening of Turkish White Cheese Made of Pasteurized Cows' Milk. Int J Food Prop, 9: 665678, doi: 10.1080/10942910500542238.

TÜİK (2020). Süt ve Süt Ürünleri Raporu Say1: 33697, https://ulusalsutkonseyi.org.tr/wpcontent/uploads/Haber_Bulteni_mart_2020.pdf (Erişim Tarihi: 10 Temmuz 2020).

Tunail, N. (2009). Mikrobiyoloji. Pelin Ofset Tipo Matbaacıllk, Ankara, Türkiye, 434 s. ISBN: 978605-603-62-0-0.

Verce, M., Vuyst, L.D., Weckx, S. (2020). The metagenome-assembled genome of Candidatus Oenococcus aquikefiri from water kefir represents the species Oenococcus sicerae. Food microbiol, 88: 103402, doi: 10.1016/j.fm.2019.103402. 
Walsh, A. M., Crispie, F., Kilcawley, K., O'Sullivan, O., O'Sullivan, M. G., Claesson, M. J., Cotter, P. D. (2016). Microbial Succession and Flavor Production in the Fermented Dairy Beverage Kefir. mSystems, 1(5): e00052-16, doi: 10.1128/mSystems.00052-16.

Wei, Y. J., Wu, Y., Yan, Y. Z., Zou, W., Xue, J., Ma, W. R., Wang, W., Tian, G., Wang, L. Y. (2018). High-throughput sequencing of microbial community diversity in soil, grapes, leaves, grape juice and wine of grapevine from China. PloS one, 13(3):e0193097, doi:10.1371/journal.pone.0193097.

Weiss, H., Hertzberg, V.S., Dupont, C., Espinoza, J.L., Levy, S., Nelson, K., Norris, S., The FlyHealthy Research Team (2019). The Airplane Cabin Microbiome. Environ Microbiol, 77(1):87-95, doi: 10.1007/s00248-018-1191-3.

Wolfe, B. E., Button, J. E., Santarelli, M., Dutton, R. J. (2014). Cheese rind communities provide tractable systems for in situ and in vitro studies of microbial diversity. Cell, 158(2): 422-433, doi: 10.1016/j.cell.2014.05.041.

Wu, L., Lu, Z., Zhang, X., Wang, Z., Yu, Y., Shi, J., Xu, Z. (2017). Metagenomics reveals flavour metabolic network of cereal vinegar microbiota. Food microbiol, 62, 23-31, doi: 10.1016/j.fm.2016.09.010.

Yılmaz R., Temiz, A. Açık, L., Çelebi Keskin, A. (2015). Genetic Differentiation of Lactobacillus delbrueckii subsp. bulgaricus and Streptococcus thermophilus Strains Isolated from Raw Milk Samples Collected from Different Regions of Turkey, Food Biotechnol, 29(4): 336-355, doi: 10.1080/08905436.2015.1092091.

Zhang, L., Loh, K., Lim, J.W., Zhang, J. (2019). Bioinformatics analysis of metagenomics data of biogas-producing microbial communities in anaerobic digesters: A review. Renew. Sustain. Energy Rev, 100: 110-126, doi: 10.1016/J.RSER.2018.10.021.

Zheng J., Wittouck S., Salvetti E., Franz C.M.A.P., Harris H.M.B., Mattarelli P., O'Toole, P.W., Pot, B., Vandamme, P., Walter, J., Watanabe, K., Wuyts, S., Felis, G.E.,Gänzle, M.G., Lebeer, S. (2020). A taxonomic note on the genus Lactobacillus: description of 23 novel genera, emended description of the genus Lactobacillus beijerinck 1901, and union of Lactobacillaceae and Leuconostocaceae. Int J Syst Evol Microbiol, 70(4): 2782-2858, doi: 10.1099/ijsem.0.004107.

Zhou, L.M., Proctor, L.M., Creasy, H., Fettweis, J.M., Lloyd-Price, J., Mahurkar, A., Zhou, W., Buck, G.A., Snyder, M.P., Strauss, J.F., Weinstock, G.M., White, O.L., Huttenhower, C. (2019). The Integrative Human Microbiome Project. Nature, 569: 641-648, doi: 10.1038/s41586-019-1238-8. 